\title{
USING FUZZY LOGIC TO CONTROL DYNAMIC LOADS ON ROAD-BUILDING MACHINE CONSTRUCTION ELEMENTS
}

\author{
Koval O. A. ${ }^{1}$, Minka S. V. ${ }^{2}$, \\ ${ }^{1}$ Kharkiv National Highway University, \\ ${ }^{2}$ Semen Kuznetsov Kharkiv National Economic University
}

\begin{abstract}
The results of researches concerning the application of fuzzy set theory for the classification of results of control of dynamic loads on the elements of construction of road-building machines are presented.
\end{abstract}

Keywords: road-making machine, fuzzy logic, classification, membership function, term-set, fuzzy set, diagnostics.

\section{Introduction}

As the construction and road works grow, an increasingly important task is to ensure the uptime of the equipment. In the road building, mostly circular machines are used. These machines are more dynamic, especially motor graders, bulldozers, scrapers etc. We will consider the motor grader as the object of the research. A motor grader is a complex dynamic system that operates in rigid dynamic loads that have a random stochastic nature. Hereat, the forces of inertia act as additional external loads on the elastic system. The interaction of the forces of inertia and the forces of elasticity under dynamic loading generate elastic vibrations, which lead to a significant increase in the total load on the nodes of the motor grader.

During operation, the graders interact with the soil with their dump (attachments). According to the research [1], the amplitude of the cutting force of solid and frozen soils averages 0.7 maximum value and is random. The above fluctuations of the force cause dynamic actions on the working equipment, which are accompanied by deformation of the blade and bearing structure of the motor grader. Depending on the load on the working body, the mode of operation of the engine, its temperature, detonation, vibration degree of the engine and other characteristics will change. The overall assessment of these diagnostic parameters requires the decision on the technical condition of the road-building machine as a whole.

Thus, it is possible to conclude the need to control the technical condition of earth moving vehicles (EMV) taking into consideration dynamic loads. The analysis of the on-board systems for diagnosing the technical state of the EMV showed that these systems do not take into consideration the dynamic loads acting on the frame and the operating elements of the ma- chines at all. This disadvantage can be eliminated if, in real time, according to current measurements of critical parameters, to classify the dynamic loads and corresponding to them dynamic modes of operation and evaluate the technical state of the EMV. One solution to this problem is to use fuzzy logic.

\section{The analysis of publications}

The researches devoted to the identification of nonlinear dependencies based on fuzzy sets and fuzzy logic has been intensively conducted abroad since the 1990s [2, 6, 23]. Among the Russian-language publications, we would mention a series of articles by Professor A.P. Ronstein $[2,3]$, which developed the method of twostep identification of nonlinear dependencies using fuzzy knowledge bases. The practical application of fuzzy set theory involves the presentation of state parameters in the form of linguistic variables. The formalization of linguistic meanings within the theory of fuzzy sets is carried out through membership functions (MFs) [1-23]. The most widespread methods of constructing MFs are based on the statistical processing of expert information and on paired comparisons [4-6, 18-23]. These methods are mainly used in the development of pure expert systems that apply only expert knowledge [710]. In [11], the method for constructing the membership functions of the information parameters of the dynamic modes of operation of a road-building machine is presented, which allows recognizing the dynamic loads depending on their stationarity.

\section{The aim and problem statement}

The purpose of this research is to substantiate the methodology of using fuzzy logic for the classification of dynamic loads of the EMV. The purpose is due to the necessity of solving a 
number of problems: substantiation of the choice of MFs and their construction, control of dynamic loads using the theory of fuzzy sets.

\section{The results of the research and them discussion}

The formal representation of a fuzzy set does not impose any restrictions on the choice of a particular EMV for its representation. However, in practice, it is convenient to use those functions that allow analytical representation in the form of a simple mathematical function. It not only simplifies the corresponding calculations, but also reduces the computational resources required to store the individual values of these MFs. Usually, the MF has two, three or four parameters. There are many types of parametric MFs, the most common are triangular, trapezoidal, and the MF of Gaussian type.

When selecting and constructing MFs, we will follow the rule that is determined by the nature of the uncertainty that occurs when constructing specific MFs. The more the value of the diagnostic parameter $x \in X$ refers to the properties that characterize the technical state of the EMV, the closer to "one» the value of the true (coefficient of membership) of the corresponding $\mathrm{MF}$ for the given diagnostic parameter should be. Conversely, the less the value of the diagnostic parameter $x \in X$ relates to the properties that characterize the technical state of the EMV, the closer to zero the value of the truth of this MF should be. If the value of the diagnostic parameter $x \in X$ does not correspond at all to the properties characterizing the technical state of the EMV, then, accordingly, the coefficient of membership will be equal zero. If the value of the diagnostic parameter $x \in X$ corresponds to the properties that characterize the technical state of the EMV, then, accordingly, the coefficient of membership will be equal one.

Direct and indirect methods have become most widespread in the construction of MFs of fuzzy sets. We will use the direct method of constructing a MF. This method is applied to the properties that can be measured on a quantitative scale. For example, diagnostic parameters such as pressure, deformation, temperature, etc., have the appropriate units and standards for their measurement. In the course of the direct method of constructing the EMV, it is necessary to take into consideration the fact that the theory of fuzzy sets does not require an accurate representation of MF. Often, it is enough to record only the most characteristic values and the type of a MF.
With the recommendations considered, we will determine the type of MF for linguistic variables, which are represented by the diagnostic parameters that characterize both the dynamic load, the mode of operation and the technical state of the EMV. For this purpose, firstly, it is necessary to determine the linguistic variables and the corresponding term-sets of the diagnostic parameter.

We will consider the fuzzy set $G$ that characterizes the deformation of the frame of EMV $G=$ «deformation on the frame» and the corresponding term sets s small, medium, large, critical\}. To represent the properties of a fuzzy set, characterized by the uncertainty of the type: «small number», «small value», «small value», a Z-curve (spline function) is usually used. Considered all round, this function can be analytically defined by the following:

$$
f_{z}(x, a, b)=\left\{\begin{array}{ll}
1, & x \leq a \\
1-2 \cdot\left(\frac{x-a}{b-a}\right)^{2}, & a<x \leq \frac{a+b}{2} \\
2 \cdot\left(\frac{b-x}{b-a}\right)^{2}, & \frac{a+b}{2}<x<b \\
0, & b \leq x
\end{array},\right.
$$

where $a$ is the numerical value of the diagnostic parameter, the coefficient of membership of which to a given MF is one; $b$ is the numerical value of the diagnostic parameter, whose coefficient of membership to a given MF equals zero. The condition $a<b$ must be satisfied. The graph of this function for the fuzzy set $G$ is shown in Fig. 1.

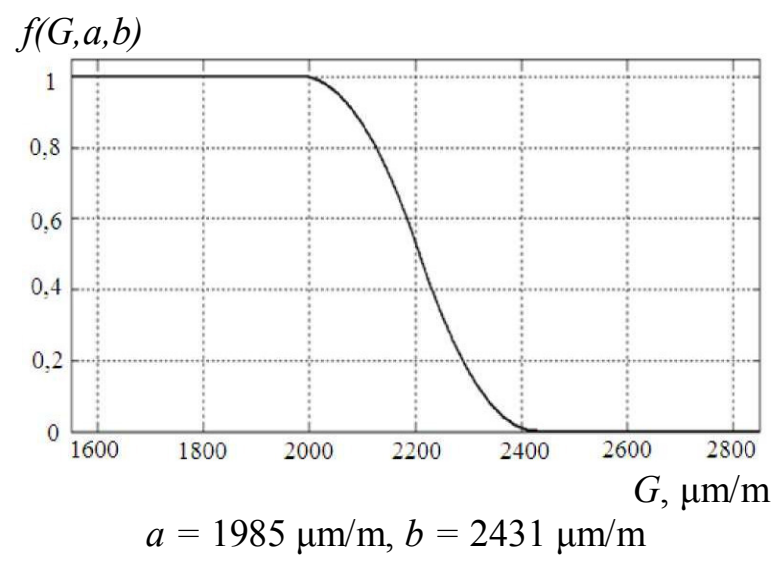

Fig. 1. Z-shaped MF of the «small deformation»

The analysis of the results of the studies of dynamic loads on the main frame and the opera- 
tional elements of the motor grader showed that, depending on the magnitude of the load, it is necessary to use different MFs. We will construct MFs that characterize the term-set «small deformation» on the frame of the motor grader. The graphs of these MFs are shown in Fig. 2.

For term sets «average deformation» and «large deformation», we will use a triangular MF, characterized by uncertainty of the type: «approximately equal», «average», «located in the interval». Considered all round, this function can be analytically defined by the following:

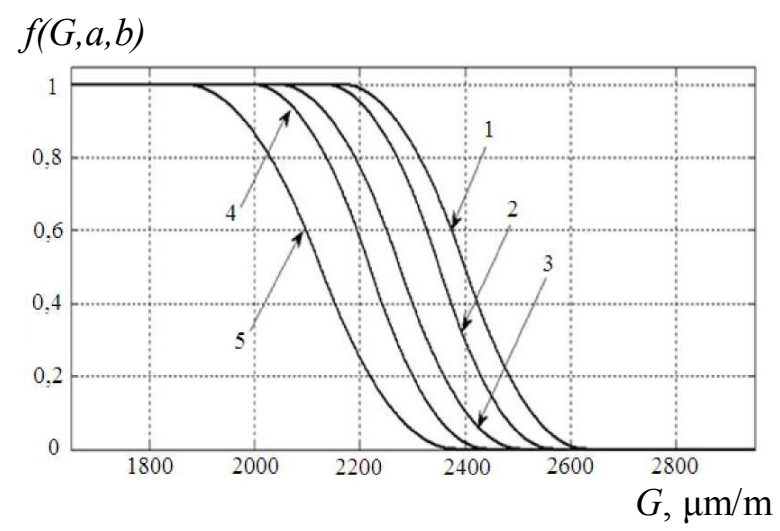

$1-a=2167 \mu \mathrm{m} / \mathrm{m}, b=2631 \mu \mathrm{m} / \mathrm{m}$;

$2-a=2134 \mu \mathrm{m} / \mathrm{m}, b=2567 \mu \mathrm{m} / \mathrm{m}$;

$3-a=2045 \mu \mathrm{m} / \mathrm{m}, b=2506 \mu \mathrm{m} / \mathrm{m}$;

$4-a=1995 \mu \mathrm{m} / \mathrm{m}, b=2442 \mu \mathrm{m} / \mathrm{m}$;

$5-\mathrm{a}=1867 \mu \mathrm{m} / \mathrm{m}, \mathrm{b}=2383 \mu \mathrm{m} / \mathrm{m}$

Fig. 2. MF of the term «small deformation» of the term-set with different parameters

$$
f_{\Delta}(x, a, b)= \begin{cases}0, & x \leq a \\ \frac{x-a}{b-a}, & a \leq x \leq b \\ \frac{c-x}{c-b}, & b \leq x \leq c \\ 0, & c \leq x\end{cases}
$$

where $a, c$ are the numerical values of the diagnostic parameter that characterize the basis of the MF triangle. The coefficient of membership of the values for this MF equals zero; $b$ is the vertex of the triangle, the coefficient of membership for this value equals one. The condition $a<b<c$ must be satisfied.

The MFs constructed according to the results of experimental studies characterizing the termset «medium deformation» and «large deformation» are presented in Fig. 3 and Fig. 4.

The conducted researches have shown that for the representation of the term-set «critical deformation» it is necessary to use a MF, which is characterized by uncertainty of the type: «large number», «large value». The MF that characterizes the uncertainty of this type is an Sshaped function.

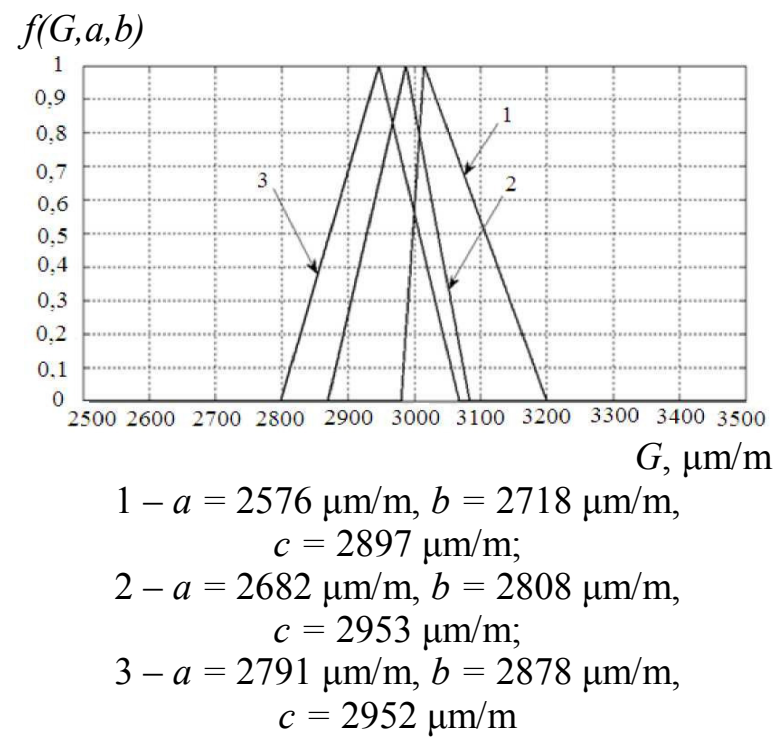

Fig. 3. MF of the term-set «average deformation» with different parameters

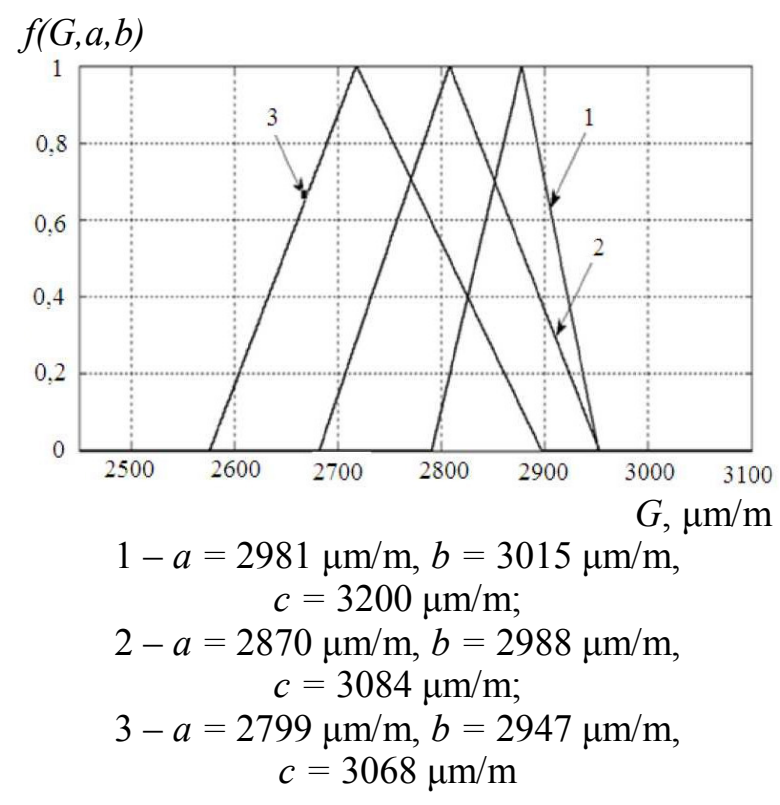

Fig. 4. MF of the «large deformation» term-set with different parameters

In the general case, this function is defined by an analytical expression:

$f_{s}(x, a, b)=\left\{\begin{array}{ll}1, & x \leq a \\ 1-2 \cdot\left(\frac{x-a}{b-a}\right)^{2}, & a<x \leq \frac{a+b}{2} \\ 2 \cdot\left(\frac{b-x}{b-a}\right)^{2}, & \frac{a+b}{2}<x<b \\ 0, & b \leq x\end{array}\right.$, 
where $a$ is the numerical value of the diagnostic parameter, the coefficient of membership of which to a given MF equals zero; $b$ is the numerical value of the diagnostic parameter, whose coefficient of membership to a given MF equals one. The condition $a<b$ must be satisfied.

The model of this function for the criticaldeformation term-set is shown in Fig. 5.

The process of finding MF values of fuzzy sets (terms) based on initial data is called phasing. The set of built-in MF forms a kind of database of these functions in the system of fuzzy inference.

$f(G, a, b)$

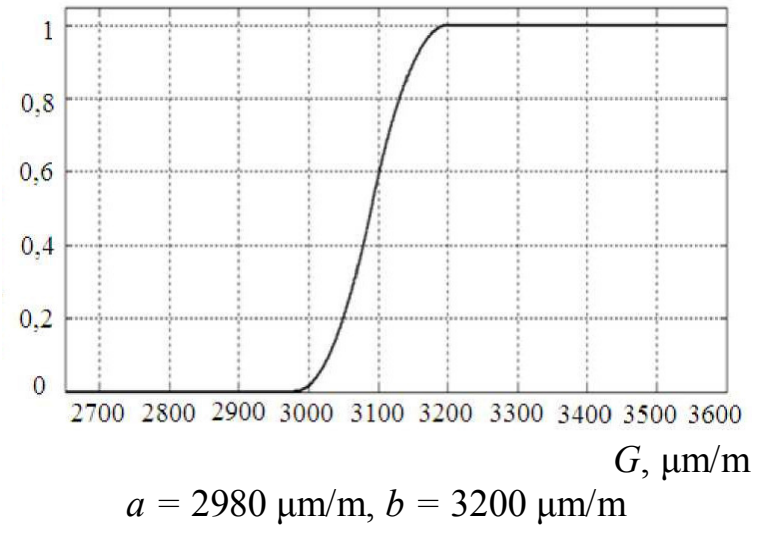

Fig. 5. S-shaped MF term «critical deformation» for parameter values

The classification of dynamic loads is carried out by comparing the values of the current measurements of the diagnostic parameter with the MF, by determining the coefficients of membership of this value to each MF. The calculation of the weighting coefficients for each measured value of the diagnostic parameter is determined by formulas (1-3).

To reflect the implementation of the dynamic load classification step, we will consider an example of deformation of the frame of the motor grader. Suppose that the current measured deformation of the frame is equal to $2654 \mu \mathrm{m} / \mathrm{m}$. As we can see from Fig. 6.

The deformation at $2654 \mu \mathrm{m} / \mathrm{m}$ corresponds to four values of the coefficient of membership: for MF, the «small deformation» is equal to 0 ; for $\mathrm{MF}$ «average deformation»-0,9; for $\mathrm{MF}$ «large deformation» - 0; for MF «critical deformation» -0 . The largest value of the coefficient of membership is the decision on the ratio of the measured value of deformation to one of the term-set \{small, medium, large, critical\}.

Thus, based on the obtained calculation data, it can be concluded that the deformation of the frame at $2654 \mu \mathrm{m} / \mathrm{m}$ corresponds to the «average deformation».

$f(G, a, b)$

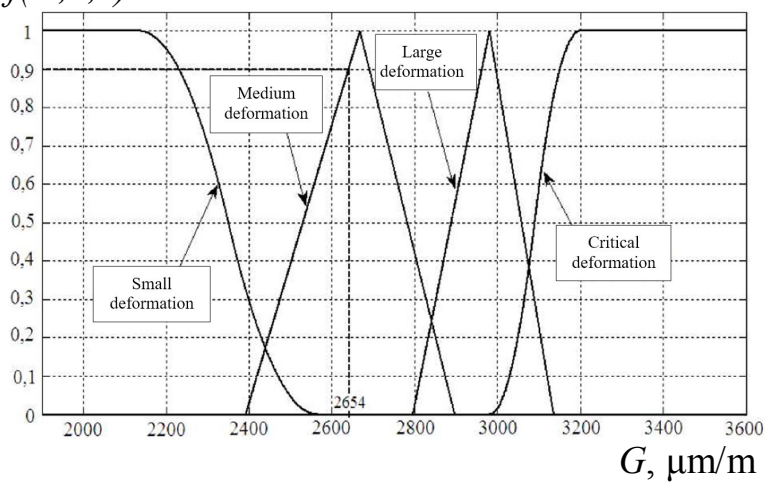

Fig. 6. The example of determining the coefficient of membership of the linguistic variable «frame deformation» for four MFs.

Similar MFs are constructed for each diagnostic parameter, characterizing both dynamic loads, operating modes and technical state of the EMV: engine temperature, pressure in the cylinders, crankshaft rotation, frame vibration, etc. Thus, many-parametric classification of such dynamic loads is carried out, as well as of the modes of operation of individual units and modules of the EMV. According to the results of the classification, based on fuzzy logical conclusions, in the future it is possible to build a multi-level on-board diagnostic system of the road-building machine.

\section{Conclusion}

The proposed approach to the classification of dynamic loads is practically valuable because in the real time scale in the working process of a road-building machine, its technical condition can be diagnosed. The dynamic load identification with the use of fuzzy logic is an effective method that takes into consideration the uncertainty of the object of diagnosis.

\section{References}

1. Zadeh, L. A. (2013). Fuzzy logic. In Computational Complexity: Theory, Techniques, and Applications (Vol. 9781461418009, pp. 1177-1200). Springer New York. https://doi.org/10.1007/9781-4614-1800-9_73.

2. Lee, C. C. (1990). Fuzzy Logic in Control Systems: Fuzzy Logic Controller, Part II. IEEE Transactions on Systems, Man and Cybernetics, 20(2), 419-435. https://doi.org/10.1109/21.52552.

3. Williams, J. K. (2009). Introduction to fuzzy logic. In Artificial Intelligence Methods in the Environmental Sciences (pp. 127-151). Springer Netherlands. https://doi.org/10.1007/978-1-40209119-3. 
4. Suganthi, L., Iniyan, S., \& Samuel, A. A. (2015, August 1). Applications of fuzzy logic in renewable energy systems - A review. Renewable and Sustainable Energy Reviews. Elsevier Ltd. https://doi.org/10.1016/j.rser.2015.04.037.

5. Bai, Y., \& Wang, D. (2006). Fundamentals of fuzzy logic control - fuzzy sets, fuzzy rules and defuzzifications. In Advances in Industrial Control (pp. 17-36). Springer International Publishing. https://doi.org/10.1007/978-1-84628-4694_2.

6. McBratney, A. B., \& Odeh, I. O. A. (1997). Application of fuzzy sets in soil science: Fuzzy logic, fuzzy measurements and fuzzy decisions. In Geoderma (Vol. 77, pp. 85-113). https://doi.org/10.1016/S0016-7061(97)00017-7.

7. Gadzhiev D. N., Tagiev E. G., Gadzhiev N. D., Shikhlinskaya R. Y. Application of fuzzy mathematical model of decision-making for the selection of optimal surgical tactics in patients with non-tumor obstructive jaundice. Kazan Med. J., 2018.

8. Klindtworth M. Elektronikeinsatz in der Rinderhaltung - Von der elektronischen Tierkennzeichnung zum Gesundheitsmanagement: Aktueller Stand und Entwicklungsperspektiven. VDI Berichte, 2004.

9. Park S. E., Moon W. M. Unsupervised classification of scattering mechanisms in polarimetrie SAR data using fuzzy logic in entropy and alpha plane,» in IEEE Transactions on Geoscience and Remote Sensing. 2007.

10. Herrmann H., Bucksch H. Fuzzi logic, in Dictionary Geotechnical Engineering/Wörterbuch GeoTechnik, 2014.

11. Afonso A. C. M., Maciel Netto A. C. M., de Vasconcelos W. E. Lógica fuzzi aplicada para modelar a dinâmica da água num latossolo na região nordeste do Brasil. Rev. Bras. Cienc. do Solo. 2014.

12. Xiong W. J., Xu Z. Q., Wang H. Privacy level evaluation of differential privacy for time series based on filtering theory. Tongxin Xuebao/ Journal Commun. 2017. Vol. 38/ No. 5. PP. 172181.

13. Zhang H., Roth E., Haeberlen A., Pierce B. C., Roth A. Fuzzi: a three-level logic for differential privacy. Proc. ACM Program. Lang. 2019.

14. Omana M., Rossi D., Fuzzi F., Metra C., Tirumurti C., Galivache R. Novel approach to reduce power droop during scan-based logic BIST in Proceedings. 2013. 18th IEEE European Test Symposium, ETS .

15. Biryulin V. I., Gorlov A. N., Kudelina D. V. Use of the Fuzzi Inference System for Evaluation of the Cable Lines Insulation State. 14th International Scientific-Technical Conference on Actual Problems of Electronic Instrument Engineering, APEIE 2018: Proceedings, 2018.

16. Cordero P., Enciso M., Mora Á., Pérez de Guzman I. A complete logic for fuzzy functional dependencies over t-norms. $X V$ Congreso
Español Sobre Tecnologías y Lógica Fuzzy. 2010, ESTYLF .

17. Gadzhiev D. N., Tagiev E. G., Gadzhiev N. D., Shikhlinskaya R. Y. Application of fuzzy mathematical model of decision-making for the selection of optimal surgical tactics in patients with non-tumor obstructive jaundice. Kazan Med. J. 2018.

18. Zhang H., Roth E., Haeberlen A., Pierce B. C., Roth A. Fuzzi: a three-level logic for differential privacy,» Proc. ACM Program. Lang., 2019.

19. El Yacoubi S. Mingarelli A. B. An algebraic characterization of fuzzy cellular automata,» J. Cell. Autom. 2011.

20. Brandão E. D. S., Dos Santos I., Lanzillotti R. S. Contribuições do cuidado de enfermagem na redução da dor em clientes com dermatoses imunobolhosas: avaliação pela lógica fuzzi. Online Brazilian J. Nurs. 2016.

21. Omana M., Rossi D., Fuzzi F., Metra C., Tirumurti C. C., Galivanche R. Scalable Approach for Power Droop Reduction during Scan-Based Logic BIST,» IEEE Trans. Very Large Scale Integr. Syst. 2017.

22. Пелевін Л. Є. Визначення працездатності робочих органів землерийних машин. Л, 2011. $213 \mathrm{c}$.

23. Ротштейн А. П. Интеллектуальные технологии идентификации: нечеткая логика, генетические алгоритмы, нейронные сети. Винница: УНИВЕРСУМ, 1999. $320 \mathrm{c}$.

24. Митюшкин Ю. И. Soft-Computing: идентификация закономерностей нечеткими базами знаний. Винница: УНИВЕРСУМ. Винница, 2002. $145 \mathrm{c}$.

25. Яхъяева Г. Э. Нечеткие множества и нейронные сети: учеб. пособие Москва: ИнтернетУниверситет Информационных технологий; БИНОМ. Лаборатория знаний, 2006. $316 \mathrm{c}$.

26. Вікторова О. В. Методика побудови функцій приналежності інформативних параметрів динамічних режимів роботи дорожньої машини. Восточно-Европейский журнал передовых технологий. 2011. № 5/3(53). С.11-15.

Oleksandr Koval, $\mathrm{PhD}$ (Tech), associate Professor, Department of Metrology and life safety, Kharkiv national automobile and highway University. 25, Yaroslava Mudrogo str., Kharkiv, 61002, Ukraine. tel: (068) 606-20-67, e-mail: koval_al@ukr.net.

ORCID ID: https://orcid.org/0000-0001-5690-2749,

Sergey Minka, $\mathrm{PhD}$ (Tech), associate Professor, Department of environmental technologies, ecology and life safety. Semen Kuznetsov kharkiv national economic university. Prospect of Science 9-a, Kharkiv, Ukraine. 61166. Tel: (050) 301-44-85, e-mail: newway1405@ukr.net.

ORCID ID: https://orcid.org/0000-0002-5952-8139. 
Применение нечеткой логики для контроля динамических нагрузок на элементы конструкции дорожной машины

Аннотация. Приведень результаты исследований по применению теории нечетких множеств для классификачии результатов контроля динамических нагрузок на элементы конструкиии дорожных машин.

Ключевые слова: дорожная машина, нечеткая логика, классификащия, функция принадлежности, терм-множество, нечеткое множество, диагностика.

Коваль Александр Андреевич, к.т.н., доцент кафедры метрологии и безопасности жизнедетельности, тел. +38-068-606-20-67, e-mail: koval_al@ukr.net.

ORCID ID: https://orcid.org/0000-0001-5690-2749.

Харьковский национальный автомобильнодорожный университет, ул. Ярослава Мудрого, 25 , г. Харьков, 61002, Украина,

Минка Сергей Викторович, к.т.н., доцент кафедры природоохранных технологий, экологии и безопасности жизнедеятельности, тел. +38-050-301-4-485, e-mail: newway1405@ukr.net. ORCID ID: https://orcid.org/0000-0002-5952-8139.

Харьковкий национальный экономический университет, проспект Науки 9-А, г. Харьков, 61166, Украина.

Використання нечіткої логіки для контролю динамічних навантажень на елементи конструкції дорожньої машини

Анотація. Проблема. Аналіз бортових систем діагностування технічного стану дорожніх машин продемонстрував, щчо ичі системи взагалі не враховують динамічні навантаження, які діють на раму та на робочі органи машин. Цей недолік можна усунути, якщо в режимі реального часу за даними поточних вимірювань критичних параметрів класифікувати динамічні навантаження та відповідні їм динамічні режими роботи ци здійснити оцінку технічного стану машини. Одним з варіантів вирімення изього завдання є використання нечіткої логіки. Мета. Обгрунтування методики застосування нечіткої логіки для контролю динамічних навантаженнь на елементи конструкиії дорожньої машини в процесі здійснення технологічних операцій. Методологія. Результати отримані на основі всебічного аналізу результатів експериментальних досліджень впливу критичних навантажень на елементи конструкиії дорожньої машини в проиесі здійснення технологічних операції на різних грунтах.
Завдання на дослідження полягає в розробијі та всебічному аналізі нечітких алгоритмів вимірювань $і$ контролю критичних динамічних навантажень на елементи рами автогрейдера. Результати. Проведені дослідження продемонстрували, щзо для середніх грунтів (які покривають 70 \% площзі території України) поточна виміряна деформаиія рами автогрейдера становить 2654 мкм/м. Ця деформачія відповідає чотирьом значенням коефіиієнта належності: «мала деформація» - 0; «середня деформачія» - 0,9; «велика деформачія»-0; «критична деформачія» - 0. За найбільшим значенням коефіцієнта належності виміряне значення деформації було класифіковано як»середня деформачія». Необхідно зазначити, щзо рішення приймалось за усередненими даними датчиків. 5 датчиків були розташовані на рамі автогрейдера та 2 на робочому органі. Дослідження продемонстрували, щзо для проведення кластеризації динамічних навантажень дорожньої машини з достовірністю 0,95 необхідно використовувати не менше 10 датчиків на рамі, 7 на робочому органі та 6 на гідрочиліндрах робочого органу автогрейдера. Якще не дотримуватись изих вимог, то достовіність кластеризації знизиться до 0,73. Оригінальність. Вперше методологію нечітких множин було застосовано для контролю динамічних навантажень на елементи конструкиї дорожньої машини в прочесі здійснення технологічних операцій. Практичне значення. Отримані результати можуть бути використані для процесу розробляння інтелектуальних бортових систем діагностики технічного стану конструктивних елементів дорожньої машини.

Ключові слова: дорожня машина, нечітка логіка, класифікація, функиія належності, терммножина, нечітка множина, діагностика.

Коваль Олександр Андрійович, к.т.н., доцент, доцент кафедри метрології та безпеки життєдіяльності, тел. (068)-606-20-67, e-mail: koval_al@ukr.net. ORCID ID: https://orcid.org/0000-0001-5690-2749

Харківський національний автомобільнодорожній університет, вул. Ярослава Мудрого, 25, м. Харків, 61002, Україна,

Мінка Сергій Вікторович, к.т.н., доцент, доцент кафедри природоохоронних технологій, екології та безпеки життєдіяльності, тел. +380503014485, e-mail: newway1405@ukr.net.

ORCID ID: https://orcid.org/0000-0002-5952-8139

Харківський національний економічний університет імені Семена Кузнеця, проспект Науки 9-А, м. Харків, 61166, Україна. 